\title{
Cointegration between macroeconomic factors and the exchange rate USD/CNY
}

\author{
Muhammad Kamran Khan®i, Jian-Zhou Teng ${ }^{*}$ and Muhammad Imran Khan
}

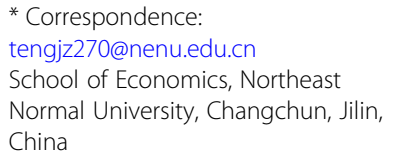

\begin{abstract}
This research paper investigates the effect of macroeconomic variables on the exchange rate USD/CYN using yearly time series data for China economy from 1980 to 2017. ARDL bounds test approach for cointegration is applied to test the long-run relation between the dependent and the independent variables. The results of long-run ARDL indicate that gross domestic product growth and trade openness have a positive effect on the exchange rate USD/CNY while interest and inflation rates have a negative effect on the exchange rate. Based on the results of this study, it is recommended that the policymakers of the Chinese government should implement vital monetary and fiscal policies to determine the less volatile and productive exchange rate for China to manage sustainable economic growth for a long time with its trading partners.
\end{abstract}

Keywords: Exchange rate, Macroeconomic factors, ARDL

JEL classification: F62, F31, C22

\section{Introduction}

Exchange rate is the value of one country's currency into another country's currency. Different economists argue that a flexible exchange rate is considered to be an important factor for any economy. Moffett et al. (2017) categorized exchange rate into four types. The fixed exchange rate is controlled by the government, which is using country's reserves for a specific time period. Managed floating exchange rate is the rate based on the demand and supply of specific currencies under certain interaction of the government. Freely floating rate is the exchange rate that fully relies on the force of demand and supply at an open market, without any government interaction. The last type of exchange rate is pegged exchange rate - when home currency is pegged as compared to the currency of another country, and both countries are similar as compared to other countries' currencies (Moffett et al., 2016; Piana 2001). Nowadays floating and pegged exchange rates are the most popular exchange rates. The floating exchange rate is adopted by the US, Europe, Japan for international trade and the currencies of these countries depend on how the currency trades in foreign exchange markets.

Countries having international trade relation with other countries should maintain the stability of their currencies. To protect against the currency depreciation countries will choose to peg their currency for their exported goods and services. Saudi Arabia,

(c) The Author(s). 2019 Open Access This article is distributed under the terms of the Creative Commons Attribution 4.0 International License (http://creativecommons.org/licenses/by/4.0/), which permits unrestricted use, distribution, and reproduction in any medium, provided you give appropriate credit to the original author(s) and the source, provide a link to the Creative Commons license, and indicate if changes were made. 
Qatar, Oman and Jordan with different Middle East countries that export oil to other countries has pegged their country currencies to USD since the US is the largest oil importing country in the world. Morrison and Labonte (2013) stated that China started to peg CNY to dollar at $8.2770 \mathrm{CNY}$ per USD back in 1995. The CNY exchange rate against USD remained to be constant from August 1995 to July 2005. Starting in 1995, $\mathrm{CNY}$ has been appreciating over the next 3 years since some of its major trading partners have forced the country to switch to the managed peg system. China stopped CNY appreciation in July 2008 because the global economic crisis was impacting China's exporters. However, it was appreciated again in June 2010. The consequences of China's currency policy for the US economy are complicated. When CNY is depreciated - it makes China's products become cheaper as compared to the United States product. Therefore, it encourages US consumers demand more Chinese products and US firms import Chinese products.

One of the most important factors affecting exchange rate is the gross domestic product growth rate. Azid et al. (2005) revealed that economic growth affects positively the exchange rate. The exchange rate of any country can be affected by its inflation rate. Purchasing power parity theory endeavored to find that in different countries having fluctuating exchange rates, equilibrium in exchange will happen when buyers in these countries hold similar buying power. Engel and Rogers (2001) study show that if any country has a greater price level of different commodities, the home currency of that country will be facing depreciation in exchange rates as compared to other countries. Smith (1999) stated that higher inflation rates minimalize the competitiveness of the country in international market with its trading partners. High inflation rate minimizes the country's export and minimalize the demand of local currency. Kulkarni and Ishizaki (2002) pointed out that the high inflation rate causes a lower value of the home currency. Fisher (1930) revealed that nominal interest rates and inflation rate have association with each other. High interest rate boosts inflation in any country and higher inflation rate causes depreciation in a host country currency. Drine and Rault (2006), Hau (2002), Lartey et al. (2008) and Xiaopu (2002) revealed that trade openness shows the margin of trade between different countries and economies. Trade openness has positive and negative impacts on the exchange rate of any country with its trading country. MacDonald and Ricci (2005) stated that high imports from other countries decrease the supply of foreign currencies, thus depreciating home currency.

In this research, United States Dollar is treated as a home currency as compared to Chinese Yuan because both countries have trading relationship with each other. China is the top exporter to the United States and it has been ranked the first largest trading partner of the USA in 2015 according to the United States Census Bureau. Annual time series data is applied for the analysis of data from 1980 to 2017. The main objective of this research paper is to investigate the macroeconomic factors which affect the exchange rate in China. ARDL bond testing is used for cointegration to determine the long- and short-run relationship between the dependent and independent variables of the study. This research contributes to the literature in different unique ways of analysing the key macroeconomic factors of the exchange rate in China for the first time. This research study is a pioneering effort to examine exchange rate's macroeconomic factors of China. From the start of the floating exchange rate regime, China is facing depreciation in its home currency. Therefore, this is very important to investigate in 
detail, the reasons of such impulsiveness of the exchange rate in China. In this research paper, we applied newly developed statistical method autoregressive distributed lag (ARDL) cointegration framework to investigate the long run and short run relationship among the study variables. Autoregressive distributed lag (ARDL) cointegration method has different advantages as compared to traditional cointegration methods. Autoregressive distributed lag (ARDL) approach makes its application possible, regardless the considered variables are stationary at level or at first difference I(0), I(1) or both of them cointegrated (Pesaran \& Shin, 1999). Haug (2002) stated that Autoregressive distributed lag (ARDL) approach has also processed better properties of small samples.

\section{Literature review}

\section{Exchange rate}

Zeileis et al. (2007) investigated exchange rate regime and pointed out that China fixed the exchange rate of Chinese Yuan (CNY) against the USD for the time period 19952005 and the exchange rate for that time duration remain constant. Zeileis et al. (2005) studied Chinese Yuan regime and pointed out that the exchange rate between CNY and USD remained fixed at 8.2770 from August 1995 to July 2005. Authors stated that different elements include inflation, nominal interest rate and government debt having an effect on the exchange rate.

\section{Inflation rate}

\section{Demand pull theory}

Inflation is the unremitting and unrepressed increasing in price level of goods and services that subsequently decrease the purchasing power of currency and economic growth of any economy. Demand pull theory stated that inflation increases when demand of goods and services increase as compared to aggregate demand for goods and services. Namjour et al. (2014) categorized inflation into three different types. Creeping Inflation is that type of inflation, which increase within the range of 1 to $6 \%$ or 4 to $8 \%$ in 1 year. The other type of inflation is severe inflation in this type of Inflation, the price level increases rapidly as compared to Creeping Inflation, it ranges within 15 to $25 \%$ per year. The last type of inflation is very severe Inflation also known as hyperinflation is the most dangerous type of inflation; in this type of inflation the prices of goods and services increases up to $50 \%$ every six months. Inflation is very essential.

Arghyrou and Pourpourides (2016); Ebiringa and Anyaogu (2014); Nucu (2011) indicated that the increase in inflation rate decreases the value of home country and which will effect to increase the exchange rate. The inflation rate has negative effect on exchange rate according to (Necșulescu and Șerbănescu 2013; Namjour et al. 2014). Different researcher stated that the increase in the inflation rate will increase the country's currency value and the exchange rate will decrease the country. Abbas et al. (2012) conducted research on the exchange rate of African Countries and pointed out inflation rate have non-significant effect on the exchange rate.

\section{Purchasing power parity (PPP) theory}

Arghyrou and Pourpourides (2016) revealed the irregularities in the exchange rate are caused by inflation, they stated inflation and exchange rate have direct association. 
They revealed that increase in inflation rate having positively effect on any country's nominal interest rate and exchange rate. Fisher effect Theory investigated the association of inflation and interest rate, the author pointed out that the nominal interest rate and inflation rate are increasing at the same rate. They pointed out that inflation causes to boost the nominal interest rate and due to this situation in the economy the home country currency depreciate its value so the exchange rate of other countries will appreciate as compared to other countries.

Ebiringa and Anyaogu (2014) conducted a research study to investigate cointegration between the exchange rate and inflation by using time series data from 1971 to 2010 in Nigeria. They pointed out inflation rate have a positive significant effect on exchange rate in Nigeria both in the short run and long run. ARDL results indicated that exchange rate affected by inflation in a positive manner; due to growth in inflation rate support to increase exchange rate.

Namjour et al. (2014) conducted research to know the association between the inflation rate and exchange rate for Iran. They pointed out that the results of correlation and least square estimation shows that inflation and exchange rate having a negative variable relationship in the short run. They pointed out that increases in inflation rate appreciate the home country currency and that causes the decrease in the value of the home country as compared to other countries currency. Namjour et al. (2014) revealed that inflation rate having different effects on exchange rate in a different countrie's economy with a different economic system. An increase in the value of the home country is due to higher imports to other trading countries and when the imported of different goods and services increase as compared to exports so the country currency devalue its value and which causes inflation in the economy.

\section{Interest rate}

Different researchers investigated interest rate and exchange rate, and pointed out a positive association regarding interest rate and exchange rate. Appreciation in interest rates causes to increase inflation rate and which decrease the value of home currency and boost the exchange rate. Gente and León-Ledesma (2006); Tafa (2015); Chowdhury and Hossain (2014); Khan (2010) stated that increase in interest rate having an effect on exchange rate due to which the home country currency value decrease and exchange rate increase. Ebiringa and Anyaogu (2014) stated that the interest rate and exchange rate have a negative association.

Fisher (1930) conducted research to investigate the association between interest rate and exchange rate. He revealed that inflation having a positive effect on the exchange rate. He stated that an increase in interest rate will cause to increase the inflation rate in the economy and high inflation will tend to devalue the home country currency.

Tafa (2015) studied the effect of interest rate on the exchange rate. He pointed out that the interest rate and exchange rate have positive associations with each other in Albania. He argues that domestic currency increases, so interest rate also increase that causes that the home country currency value will boost against foreign currency.

Liew et al. (2009) investigated the association between exchange rates and its elements by using monthly time series data from $1977 / 01$ to $2006 / 03$. They revealed the results of the Johansen cointegration technique show that the interest rate and GDP have a negative effect on exchange rate in Thailand. 
Chowdhury and Hossain (2014) studied the association of interest rate and exchange rate of Bangladesh. They revealed that a positive association exists among interest rate and exchange rate in Bangladesh.

Gente and León-Ledesma (2006) examined the basic elements of exchange rates for four countries by using panel data from 1980 to 2001. They used the Johansen cointegration method for estimation and revealed that increase in World's interest rates have a negative effect on the exchange rate.

Wong (2013) endeavored to find the association between exchange rate and economic growth in Malaysia, by using time series data from 1971 to 2008. ARDL model is used to investigate the short run and the long run relation between variables of the study. The Results of ARDL approach show that the decrease in the value of exchange rate helps in the growth of the Malaysian economy. He also pointed out that higher interest rates positively affect the home country currency.

\section{Trade openness}

Siddiqui et al. (1996) assessed the exchange rate behavior for the time period 19601994 for Pakistan by applying the two-stage least square method for estimation. They pointed out that the openness of trade helps to grow the exchange rate in Pakistan, but terms of trade have negative effect on the real exchange rate.

Kumar (2010) examines the factors of the exchange rate in India by applying autoregressive distributed lag (ARDL) approach. He used time series data from 1997 Q2 to 2009 Q2. He pointed out that the terms of trade have negative significant effect on the exchange rate while trade openness has a positive and significant effect on Indian exchange rates in the long run.

Elbadawi and Soto (1997) investigated macroeconomic elements of real exchange rate by applying panel data of different countries for the period 1960-1994. They used (ECM) with cointegration method to investigate association of trade openness and real exchange rates. They pointed out that trade having a positive significant effect on exchange rates.

Bahmani-Oskooee and Tanku (2006) investigated the elements of the exchange rate by using time series data from 1970 to 1990 to 38 for African countries. They used panel data for analysis and pointed out that the results of panel regression shows that the decreases in import prices appreciate the exchange rate in the home country while an increase in export prices depreciate the exchange rates.

Joyce and Kamas (2003) used productivity and terms of trade to investigate the exchange rate, in three Latin American countries by applying annual data from 1971 to 1995 . They pointed out that Johansen's cointegration result shows a long run relationship of the exchange rate with terms of trade and productivity in Colombia, Argentina and Mexico.

Lane and Milesi-Ferretti (2012) investigated the elements the real exchange rate in Ireland by using time series data from 1970 to 1997, they pointed out that there is no connection between terms of trade and exchange rate. Johansen cointegration results show that strong and positive association between relative output and real exchange rates exists.

Mallick (2010) examines the elements of the exchange rate in India by using monthly time series data from 1994 to 2007 . They used fully modified ordinary least squares for 
analysis, results of FMOLS show that real output growth has a significant effect on the appreciation of Indian rupee.

Algieri (2011) revealed the elements of Russian Ruble exchange rate by applying time series data from 1993 to 2010, VECM and Johansen cointegration method are used for estimation. He pointed out that the trade openness has a negative effect on Russian Ruble in long run. He suggested that open economies tend to decrease the value the Russian Ruble. Hau (2002) investigated the movements of the exchange rate by using a panel data for 48 countries and pointed out that trade openness is inversely associated with the real exchange rate.

\section{Gross domestic product growth}

McPherson and Rakovski (2000) studied the association between economic growth and exchange rate. They applied time series data for econometric analysis from 1970 to 1996 for Kenya. They investigated direct and indirect association between the real and nominal exchange rates and GDP growth. Results of co-integration indicated that that there is no evidence of a strong direct relationship between changes in the exchange rate and GDP growth.

\section{Estimation techniques}

\section{Empirical framework}

After investigating the theoretical and empirical work, this research intends to investigate the effect of macroeconomic factors on the exchange rate that is derived by using the purchasing power parity theory and interest rate parity theory. Purchasing power parity regulates exchange rate through inflation. Purchasing power parity theory revealed that in different countries following fluctuating exchange rates, equilibrium will occur in these countries when similar buying power hold in these countries. Engel and Rogers (2001) study show that if any country has a greater price level of different commodities, the home currency of that country will be facing depreciation in exchange rates as compared to other countries. Interest rate parity theory stated that the growing interest rate experiences intensification in the value of their domestic currency as compared to the country's regulating lower rates and faces depreciation (Clostermann and Schnatz 2000). High exchange rate resulting from higher rates motivates investors that cause increases in capital invasions that result to improve demand for the home currency and appraises its value (Bailliu et al. 2003; Neumeyer and Perri 2005). Following the theoretical and empirical framework this model is derived:

$$
E X C R_{t}=\beta_{o}+\beta_{1} G D P G_{t}+\beta_{2} I N F R_{t}+\beta_{3} I N T R_{t}+\beta_{4} T R D O_{t}+\varepsilon_{t}
$$

In the above model $\varepsilon_{t}$ is the error term, EXCR is the currency exchange rate of Chinese Renminbi (CYN) against the United State dollar, GDPG is the percentage of gross domestic product used as a proxy of economic growth, INFR is annual inflation rate, which is computed by using the consumer price index, INTR is average annual interest rate and TRDO is trade openness which is measured by import plus export divide by GDP. All macroeconomic variables used in this study are in percentage form by using annual time-series data for the period of 1987-2016. All data used in this research paper are gathered from Federal Reserve Economic data.

\section{Unit root test}

Stationarity of data is checked with conventional stationarity tests such as the augmented (ADF) by Dickey Fuller (1979) and Phillips and Perron (PP) (1988) tests. The null hypothesis is 
the unit root with a drift against the two alternative hypotheses: the series has no unit root with a linear time trend, or the series has stationary trend having non-zero mean with no time trend.

\section{Autoregressive distributed lag (ARDL)}

Autoregressive Distributed Lag (ARDL) bounds testing approach is used to investigate the long and the short run relationship between dependent and independent variables of the study. Pesaran et al. (2001) developed ARDL. Different researchers used different popular cointegration models in literature for different situations: Engle and Granger (1987) cointegration method is the first method that is applicable for two variables in I (1) order. Johansen and Juselius (1990) is the second method of cointegration that is used for large size of data and all series have the same order of integration. These two methods have some limitation that all series should be integrated at the same level. Researcher urged to introduce a novel technique that treats the variables with different series of $\mathrm{I}(0)$ and $\mathrm{I}(1)$. At last Pesaran et al. (2001) developed Autoregressive Distributed Lag (ARDL) cointegration model to solve the issue. ARDL method is applied to deal with the variables having stationary of series mixture of $\mathrm{I}(0)$ and $\mathrm{I}(1)$. ARDL model is superior to the other cointegration model and provides reliable results for small sample size. Autoregressive Distributed Lag (ARDL) model having problem of endogeneity during estimations. Endogeneity problem can be solved by taking lags of variables and make the model dynamic as in Pesaran et al. (2001), while Engle-Granger cointegration and Johansen cointegration are not able to apply different lags of variables. However, the ARDL model has the ability to utilize different lags of variables (Ozturk and Acaravci 2011). Following is the bound test cointegrations models.

$$
\begin{aligned}
& \Delta \mathrm{EXCR}_{t}=\boldsymbol{\beta}_{\boldsymbol{o}}+\boldsymbol{\beta}_{1} \sum_{i=1}^{\boldsymbol{P}} \Delta \mathrm{EXCR}_{t-1}+\boldsymbol{\beta}_{2} \sum_{i=1}^{\boldsymbol{P}} \Delta \mathrm{GDPG}_{t-1}+\boldsymbol{\beta}_{3} \sum_{i=1}^{\boldsymbol{P}} \Delta \mathrm{INFR}_{t-1} \\
& +\boldsymbol{\beta}_{4} \sum_{i=1}^{P} \Delta \mathrm{INTR}_{t-1}+\boldsymbol{\beta}_{5} \sum_{i=1}^{P} \Delta \mathrm{TRDO}_{t-1}+\lambda_{1} \text { EXCR }_{t-i}+\lambda_{2} \mathrm{GDPG}_{t-i} \\
& +\lambda_{3} \operatorname{INFR}_{t-i}+\lambda_{4} \operatorname{INTR}_{t-i}+\lambda_{5} \operatorname{TRDO}_{t-i}+\varepsilon_{t} \\
& \Delta \mathbf{G D P G}_{t}=\boldsymbol{\beta}_{\boldsymbol{o}}+\boldsymbol{\beta}_{1} \sum_{i=1}^{\boldsymbol{P}} \Delta \mathrm{GDPG}_{t-1}+\boldsymbol{\beta}_{2} \sum_{i=1}^{\boldsymbol{P}} \Delta \mathbf{E X C R}_{t-1}+\boldsymbol{\beta}_{3} \sum_{i=1}^{\boldsymbol{P}} \Delta \mathrm{INFR}_{t-1} \\
& +\boldsymbol{\beta}_{4} \sum_{i=1}^{P} \Delta \operatorname{INTR}_{t-i}+\boldsymbol{\beta}_{5} \sum_{i=1}^{P} \Delta \text { TRDO }_{t-i}+\lambda_{1} \mathbf{G D P G}_{t-i}+\lambda_{2} \mathbf{E X C R}_{t-i} \\
& +\lambda_{3} \mathrm{INFR}_{t-i}+\lambda_{4} \operatorname{INTR}_{t-i}+\lambda_{5} \operatorname{TRDO}_{t-i}+\varepsilon_{t} \\
& \Delta \mathbf{I N F R}_{t}=\boldsymbol{\beta}_{\boldsymbol{o}}+\boldsymbol{\beta}_{1} \sum_{i=1}^{\boldsymbol{P}} \Delta \mathrm{INFR}_{t-1}+\boldsymbol{\beta}_{2} \sum_{i=1}^{\boldsymbol{P}} \Delta \boldsymbol{E X C R}_{\boldsymbol{t}-1}+\boldsymbol{\beta}_{3} \sum_{i=1}^{\boldsymbol{P}} \Delta \mathbf{G D P G}_{t-1} \\
& +\boldsymbol{\beta}_{4} \sum_{i=1}^{\boldsymbol{P}} \Delta \mathrm{INTR}_{t-1}+\boldsymbol{\beta}_{5} \sum_{i=1}^{\boldsymbol{P}} \Delta \mathrm{TRDO}_{t-1}+\boldsymbol{\lambda}_{1} \mathrm{INFR}_{t-i}+\boldsymbol{\lambda}_{2} \mathbf{E X C R}_{t-i} \\
& +\lambda_{3} \mathrm{DGDP}_{t-i}+\lambda_{4} \operatorname{INTR}_{t-i}+\lambda_{5} \operatorname{TRDO}_{t-i}+\varepsilon_{t}
\end{aligned}
$$




$$
\begin{aligned}
& \Delta \mathbf{I N T R}_{t}=\boldsymbol{\beta}_{\boldsymbol{o}}+\boldsymbol{\beta}_{1} \sum_{i=1}^{\boldsymbol{P}} \Delta \mathbf{I N T R}_{t-1}+\boldsymbol{\beta}_{2} \sum_{i=1}^{\boldsymbol{P}} \Delta \mathbf{I N F R}_{\boldsymbol{t}-1}+\boldsymbol{\beta}_{3} \sum_{i=1}^{\boldsymbol{P}} \Delta \mathbf{E X C R}_{t-1} \\
& +\boldsymbol{\beta}_{4} \sum_{i=1}^{P} \Delta \mathbf{G D P G}_{t-1}+\boldsymbol{\beta}_{5} \sum_{i=1}^{P} \Delta \mathrm{TRDO}_{t-1}+\lambda_{1} \mathbf{I N T R}_{t-i}+\lambda_{2} \mathbf{I N F R}_{t-i} \\
& +\lambda_{3} \operatorname{EXCR}_{t-i}+\lambda_{4} \operatorname{GDPG}_{t-i}+\lambda_{5} \operatorname{TRDO}_{t-i}+\varepsilon_{t} \\
& \Delta \text { TRDO }_{t}=\boldsymbol{\beta}_{\boldsymbol{o}}+\boldsymbol{\beta}_{1} \sum_{i=1}^{\boldsymbol{P}} \Delta \mathrm{TRDO}_{t-1}+\boldsymbol{\beta}_{2} \sum_{i=1}^{\boldsymbol{P}} \Delta I N T R_{t-1}+\boldsymbol{\beta}_{3} \sum_{i=1}^{P} \Delta I N F R_{t-1} \\
& +\boldsymbol{\beta}_{4} \sum_{i=1}^{P} \Delta \mathbf{E X C R}_{t-1}+\boldsymbol{\beta}_{5} \sum_{i=1}^{P} \Delta \mathbf{G D P G}_{t-i}+\lambda_{1} \text { TRDO }_{t-i}+\lambda_{2} \mathbf{I N T R}_{t-i} \\
& +\lambda_{3} \mathrm{INFR}_{t-i}+\lambda_{4} \mathrm{EXCR}_{t-i}+\lambda_{5} \mathrm{GDPG}_{t-i}+\varepsilon_{t}
\end{aligned}
$$

Where EXCR is the exchange rate, GDPG is the gross domestic product growth rate, INFR is the inflation rate, INTR is the interest rate, TRDO is the trade openness, $\beta 0$ is the constant term and $\varepsilon$ is the error term. The dynamics for error correction in the short run are represented by the terms with summation signs while the long-run relation is shown in the next half of the equation represented by $\lambda$. Autoregressive distributed lag (ARDL) technique applies Wald test ( $F$-statistics) to decide the existence of cointegration among variables. The null hypothesis of cointegration states that there is no cointegration against the alternative hypothesis of there exists cointegration between variables. Pesaran et al. (2001) present the critical values of $F$-statistics and also two types of bounds: lower bound and upper bound. If the Wald test statistics are less than the lower bound, it indicates that there is no long-term cointegration existing among variables. In contrast, the test value is higher than the upper bound range; it means there is a long-term cointegration between variables. If the $F$-statistics is within the bounds, it indicates the inconclusive result. In this study, we apply Akaike Information Criterion (AIC) for our optimal lag length selections. After selection of the lag length and model estimation, if there exists the cointegration relationship so the short run and the long run ARDL model equations are the following:

$$
\begin{aligned}
& \Delta \mathbf{E X C R}_{t}=\boldsymbol{\beta}_{\boldsymbol{o}}+\boldsymbol{\beta}_{1} \sum_{i=1}^{\boldsymbol{P}} \Delta \mathbf{E X C R}_{t-i}+\boldsymbol{\beta}_{2} \sum_{i=1}^{\boldsymbol{P}} \Delta \mathbf{G D P G}_{t-i}+\boldsymbol{\beta}_{3} \sum_{i=1}^{P} \Delta \mathrm{INFR}_{t-i} \\
& +\boldsymbol{\beta}_{4} \sum_{i=1}^{\boldsymbol{P}} \Delta \mathrm{INTR}_{t-i}+\boldsymbol{\beta}_{5} \sum_{i=1}^{\boldsymbol{P}} \Delta \mathrm{TRDO}_{t-i}+\boldsymbol{\theta}_{1} \boldsymbol{E C T}_{t-1}+\boldsymbol{\varepsilon}_{\boldsymbol{t}} \\
& \Delta \mathbf{G D P G}_{t}=\boldsymbol{\beta}_{\boldsymbol{o}}+\boldsymbol{\beta}_{1} \sum_{i=1}^{\boldsymbol{P}} \Delta \mathbf{G D P G}_{t-i}+\boldsymbol{\beta}_{2} \sum_{i=1}^{\boldsymbol{P}} \Delta \mathbf{E X C R}_{t-i}+\boldsymbol{\beta}_{3} \sum_{i=1}^{\boldsymbol{P}} \Delta \mathrm{INFR}_{t-i} \\
& +\boldsymbol{\beta}_{4} \sum_{i=1}^{P} \Delta \mathrm{INTR}_{t-i}+\boldsymbol{\beta}_{5} \sum_{i=1}^{P} \Delta \mathrm{TRDO}_{t-i}+\boldsymbol{\theta}_{2} E C T_{t-1}+\boldsymbol{\varepsilon}_{t}
\end{aligned}
$$




$$
\begin{aligned}
& \Delta \mathbf{I N F R}_{t}=\boldsymbol{\beta}_{\boldsymbol{o}}+\boldsymbol{\beta}_{1} \sum_{i=1}^{\boldsymbol{P}} \Delta \mathrm{INFR}_{t-i}+\boldsymbol{\beta}_{2} \sum_{i=1}^{\boldsymbol{P}} \Delta E X C \boldsymbol{R}_{t-i}+\boldsymbol{\beta}_{3} \sum_{i=1}^{\boldsymbol{P}} \Delta \mathrm{GDPG}_{t-i} \\
& +\beta_{4} \sum_{i=1}^{P} \Delta \operatorname{INTR}_{t-i}+\beta_{5} \sum_{i=1}^{P} \Delta \operatorname{TRDO}_{t-i}+\theta_{3} E C T_{t-1}+\varepsilon_{t}
\end{aligned}
$$

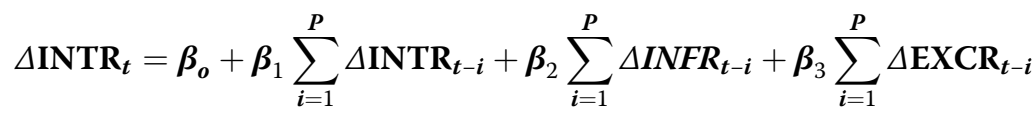

$$
\begin{aligned}
& +\beta_{4} \sum_{i=1}^{P} \Delta \mathrm{GDPG}_{t-i}+\boldsymbol{\beta}_{5} \sum_{i=1}^{P} \Delta \mathrm{TRDO}_{t-i}+\boldsymbol{\theta}_{4} E C T_{t-1}+\varepsilon_{t} \\
& \Delta \text { TRDO }_{t}=\beta_{o}+\beta_{1} \sum_{i=1}^{P} \Delta \text { TRDO }_{t-i}+\beta_{2} \sum_{i=1}^{P} \Delta I N T R_{t-i}+\beta_{3} \sum_{i=1}^{P} \Delta I N F R_{t-i} \\
& +\boldsymbol{\beta}_{4} \sum_{i=1}^{P} \Delta \mathbf{E X C R}_{t-i}+\boldsymbol{\beta}_{5} \sum_{i=1}^{P} \Delta \mathbf{G D P G}_{t-i}+\boldsymbol{\theta}_{5} \boldsymbol{E C T}_{\boldsymbol{t}-1}+\boldsymbol{\varepsilon}_{\boldsymbol{t}}
\end{aligned}
$$

In the above equations, error correction term $(E C T t-1)$ represents the long-run equilibrium speed of adjustment. Serial correlation and Heteroskedasticity test applied to check the goodness of fit of the model. Cumulative sum (CUSUM) and the cumulative sum of squares (CUSUMSQ) tests are applied for checking stability.

\section{Results and discussion}

Table 1 indicates the results of the Unit Root test for checking the stochastic properties of the data are assessed on the basis of the series of each variable through Augmented Dickey Fuller and Phillips-Perron tests. Results indicate that inflation and interest rate are stationary at level with ADF unit root test, also interest rate is stationary at level with PP while the remaining variables are non-stationary at level. All the time series variables stationarity are again checked at the first difference with both ADF and PP. The result of the first difference indicates that all variables are stationary. Thus, it

Table 1 Unit Root Test

\begin{tabular}{llllll}
\hline Variables & ADF & & & \\
\cline { 2 - 3 } \cline { 5 - 5 } & Intercept & Trend \& Intercept & & Intercept & Trend \& Intercept \\
\hline Level & & & & \\
EXCR & -2.1617 & -0.9660 & -2.1196 & -0.9762 \\
GDPG & -4.4096 & $-4.7044^{\mathrm{b}}$ & -2.8107 & -2.5251 \\
INFR & $-3.3827^{\mathrm{a}}$ & $-3.8371^{\mathrm{a}}$ & -2.4424 & -2.5542 \\
INTR & $-3.5806^{\mathrm{a}}$ & -3.5232 & $-3.6007^{\mathrm{a}}$ & -3.6311 \\
TRDO & -0.7895 & -1.4466 & -1.8110 & -0.0517 \\
First Difference & & & & \\
EXCR & $-5.1581^{c}$ & $-5.7296^{c}$ & $-5.8603^{c}$ & $-4.2031^{c}$ & $-5.7286^{c}$ \\
GDPG & $-5.9176^{c}$ & $-4.8610^{\mathrm{b}}$ & $-5.9144^{c}$ & $-6.2571^{c}$ \\
INFR & $-4.8311^{c}$ & $-6.2267^{c}$ & $-6.8773^{c}$ & $-7.3084^{c}$ \\
INTR & $-6.3198^{c}$ & $-4.4918^{\mathrm{a}}$ & $-6.6417^{c}$ & $-7.4399^{c}$ \\
TRDO & $-3.3199^{c}$ & $-4.3199^{\mathrm{b}}$ & $-4.5144^{\mathrm{b}}$ \\
\hline
\end{tabular}

$\mathrm{a}, \mathrm{b}$ and ${ }^{\mathrm{C}}$ shows 1,5 and $10 \%$ level of significance respectively 
indicates that the order of integration is a mixture of I (0) and I (1), making it valid to use Autoregressive distributed lag (ARDL) bound test approach.

Table 2 indicates the result of lag selection criteria for Autoregressive distributed lag (ARDL) model. Before applying ARDL model it is necessary to determine the optimal lag length of variables of the study. Akaike Information Criterion (AIC) and Schwarz Bayesian Criterion (SBC) are two famous methods to select best lags for variables. In this study, we used AIC for lags selection; lags two are selected for this study.

Table 3 indicates the results of bound test. Results of F-statistics revealed that cointegration exist among variables if the value of calculated F-Statistics is greater than the upper bound value at $5 \%$ level of significance. We checked cointegration of all variables by changing dependent variable one by one. The results of first equation $\mathrm{F}_{\mathrm{EXCR}}$ (EXCR) GDPG, INFR, INTR, TRDO) indicate that cointegration exist among variables when dependent variable was the exchange rate. In the second equation, we used GDP growth as dependent variable $\mathrm{F}_{\mathrm{GDPG}}(\mathrm{GDPG}$ | EXCR, INFR, INTR, TRDO), results indicates that co-integration exists among variables. Third equation also indicates long-run relationship between variable when the dependent variable is used as Inflation $\mathrm{F}_{\text {INFR }}$ (INFR| GDPG, EXCR, INTR, TRDO). Fourth revealed that co-integration exist amongst variables when interest rate is used as dependent variable $F_{\text {INTR }}$ (INTR । GDPG, INFR, EXCR, TRDO). The last equation $\mathrm{F}_{\mathrm{TRDO}}$ (TRDO | GDPG, INFR, INTR, EXCR) showed that cointegration is present among the study variables.

Table 4 indicates the result of the long run ARDL approach. Exchange rate USD/ $\mathrm{CNY}$ is used as dependent variable and Gross domestic product growth, Inflation rate, Interest rate and Trade openness are used as independent variables in this research paper.

Results of ARDL model indicate that Gross domestic product growth has positive and significant effect on exchange rate USD/CNY in the long run. Coefficient of gross domestic product growth indicates that $1 \%$ increase in gross domestic product growth, increase exchange rate USD/CNY $0.68 \%$. Our results of gross domestic product growth are consistent with Azid et al. (2005) and Mirchandani (2013) while to contradict with results of Harberger (2003). Mirchandani (2013) investigated the association between GDP and exchange rates in India and pointed out a significant positive relationship of India's economy growth with exchange rate. Azid et al. (2005) stated that that volatility in economic growth affects the exchange rate positively and significantly; the government apply non-consistent exchange rate policies in the economy. Harberger (2003) stated that economic growth and exchange rate have no relationship and economic growth non-significantly affect exchange rates.

Coefficient of inflation rate shows the negative and significant effect on exchange rate USD/CNY in China in the long run. High rate of inflation minimalize effectiveness of

Table 2 VAR Lag Order Selection Criteria

\begin{tabular}{lllllll}
\hline Lag & LogL & LR & FPE & AIC & SC & HQ \\
\hline 0 & -478.6142 & NA & 320.6609 & 26.8674 & 27.0873 & 26.9442 \\
1 & -346.5227 & 220.1524 & 849.1512 & 20.9179 & 22.2375 & 21.3785 \\
2 & -313.2510 & $46.2107^{\mathrm{a}}$ & $583.9447^{\mathrm{a}}$ & $20.4583^{\mathrm{a}}$ & $22.8776^{\mathrm{a}}$ & $21.3027^{\mathrm{a}}$ \\
\hline
\end{tabular}

$L R$ is sequentrial modified LR test statistic ( $5 \%$ level of each test), FPE is Final predication error. AIC is Akaike information criterion, $S C$ is Schwarz information criterion, $H Q$ is Hannan Quinn information criterion

${ }^{a}$ showes orders of lag selected by the criterion 
Table 3 ARDL Bounding Test

\begin{tabular}{|c|c|c|}
\hline Equations & F-Statistics & \\
\hline $\mathrm{F}_{\mathrm{EXCR}}(\mathrm{EXCR} \mid \mathrm{GDPG}$, INFR, INTR, TRDO) & 10.5852 & Co-Integration \\
\hline $\mathrm{F}_{\mathrm{GDPG}}(\mathrm{GDPG} \mid \mathrm{EXCR}$, INFR, INTR, TRDO) & 5.7123 & Co- Integration \\
\hline $\mathrm{F}_{\text {INFR }}(\mathrm{INFR} \mid \mathrm{GDPG}, \mathrm{EXCR}$, INTR, TRDO) & 6.7119 & Co-Integration \\
\hline 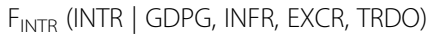 & 5.1682 & Co-Integration \\
\hline $\mathrm{F}_{\mathrm{TRDO}}(\mathrm{TRDO} \mid \mathrm{GDPG}$, INFR, INTR, EXCR) & 5.4659 & Co-Integration \\
\hline
\end{tabular}

country in international market. Results of inflation rate indicated that $1 \%$ increase in inflation in China economy causes the downfall of Chinese currency up to $0.62 \%$. Smith (1999) stated that the high inflation rate reduces export of home country due to which the demand of home country's currency decrease in international trade. Kulkarni and Ishizaki (2002) revealed that ultimately results in a lower value of the home currency due to high inflation and low demand of local currency as compared to other country.

Interest rate coefficient results indicate negative and statistically non-significant effect on exchange rate USD/CNY in the long run in China. Interest rate results indicated that the decrease in the Yuan value is caused by high interest rate in the economy, about $0.18 \%$ devaluation in exchange rate is due to $1 \%$ increase in interest rate in China economy. Results of interest rate are in line with the results of previous researchers. Khan and Qayyum (2011) stated that the interest rate has negatively and statistically non-significant affect exchange rates in Pakistan. Iqbal et al. (2012) revealed that GDP and interest rate have a negative effect on exchange rates in Pakistan.

Long run coefficient of trade openness indicates positive and statistically non-significant to determine exchange rates. Trade openness results indicate that $1 \%$ increase will boost up the exchange rate up to $0.45 \%$ per annum in China, because with trade openness China experts its products to other country through which China economy earn foreign exchange and the level and when the level of foreign exchange reserve increase in economy so the value of home currency increase. Raza and Afshan (2017) investigated elements of the exchange rate in Pakistan by using time series data from 1972 to 2013. They used autoregressive distributed lag bound testing cointegration approach, the Johansen and Juselius cointegration approach for checking long run relationship among the study variables. The result of long run cointegration shows that term of trade and trade openness have a significant and negative effect on exchange

Table 4 ARDL Long Run Approach

\begin{tabular}{lllll}
\hline Variable & Coefficient & Std. Error & t-Statistic & Prob. \\
\hline GDPG & 0.6845 & 0.2895 & 2.8559 & 0.0019 \\
INFR & -0.6220 & 0.2022 & -3.0761 & 0.0074 \\
INTR & -0.1822 & 0.2748 & -0.6630 & 0.5221 \\
TRDO & 0.4538 & 0.0882 & 5.1451 & 0.0000 \\
C & 21.2878 & 16.0625 & -1.3253 & 0.1971 \\
R-squared & & 0.9940 & Akaike info criterion & 1.5944 \\
Adjusted R-squared & & 0.9849 & Schwarz criterion & 1.0759 \\
F-statistic & & 18.9986 & Durbin-Watson stat & 1.9956 \\
Prob (F-statistic) & & & & \\
\hline
\end{tabular}


Table 5 ARDL Short Run Approach

\begin{tabular}{lllll}
\hline Variables & Coefficient & Std. Error & t-Statistic & Prob. \\
\hline D (GDPG (-1)) & 0.7010 & 0.1620 & 4.4280 & 0.0008 \\
D (INFR) & 0.1588 & 0.0466 & 3.4077 & 0.0060 \\
D (INTR) & -0.1118 & 0.0608 & -1.8388 & 0.3868 \\
D (TRDO) & 0.6880 & 0.2466 & -2.4257 & 0.0368 \\
ECT $(-1)$ & $-0 . .5786$ & 0.1867 & 3.0990 & 0.0083 \\
\hline
\end{tabular}

rate in Pakistan while money supply and inflation have a positive and significant effect on the exchange rate.

Results of descriptive statistics indicate that R-square indicates $99 \%$ variation in exchange rates is explained by the independent variables of the study. AIC and SIC values show that the model fits for analysis. Durbin Watson value is 1.99 which indicates that there is no problem of autocorrelation in the data. F statistics values show that the model is fit (Gujarati, 2003).

Table 5 indicates the results of the short run ARDL approach. Exchange rate USD/ $\mathrm{CNY}$ is used as the dependent variable. Results of short run cointegration indicate that gross domestic product growth has positive and statistically significant effect on exchange rate USD/CNY in China. The Short run ARDL results of Gross domestic product are consistent with long run results. The inflation rate has positive and statistically significant effect on exchange rate USD/CNY in china. Results of inflation rate indicate that $1 \%$ increase in inflation boost up exchange rate USD/CNY $0.1599 \%$ in the short run, which is not consistent with the result of the long run ARDL model. The interest rate has positive and non-significant effect on exchange rate in China in the short run. A reason for this could be that the Banks in China did not apply the appropriate interest rate policy to control the exchange rate, and that Chinese economic conditions are hard to estimate. Trade openness has positive and statistically significant effect on exchange rate USD/CNY in China. This authorizes a valid short-run association between exchange rate and the determinants of this study in China. The coefficient of the error term value -0.5886 suggests that about $58 \%$ of disequilibrium is corrected in the current year.

Table 6 shows the result of Breusch-Godfrey and Breusch Pagan Godfrey test for serial correlation and Heteroskedasticity respectively. The Breusch Godfrey test result indicates that there is no problem of serial correlation in the data because the $P$ Value of $\mathrm{F}$ statistics is higher than 0.05 and results of Breusch Pagan Godfrey $P$ value is also greater than 0.05 which indicate that there is no problem of Heteroskedasticity in our data.

Figures 1 \& 2 shows the graphs of CUSUM and CUSUM square respectively. CUSUM and CUSUM of square test on recursive residuals are used to check the

Table 6 Serial Correlation and Heteroskedasticity Test

\begin{tabular}{lclr}
\hline Breusch-Godfrey Serial Correlation LM Test & & \\
F-statistic & 1.0810 & \multicolumn{1}{c}{ Prob. F(223) } & 0.3559 \\
Obs $^{*}$ R-squared & 3.093239 & Prob. Chi Square (2) & 0.2130 \\
Heteroskedasticity Test: Breusch-Pagan-Godfrey & & \\
F-statistic & 2.5439 & Prob. F (25,6) & 0.1236 \\
Obs ${ }^{*}$ R-squared & 29.2413 & Prob. Chi Square (12) & 0.2540 \\
\hline
\end{tabular}




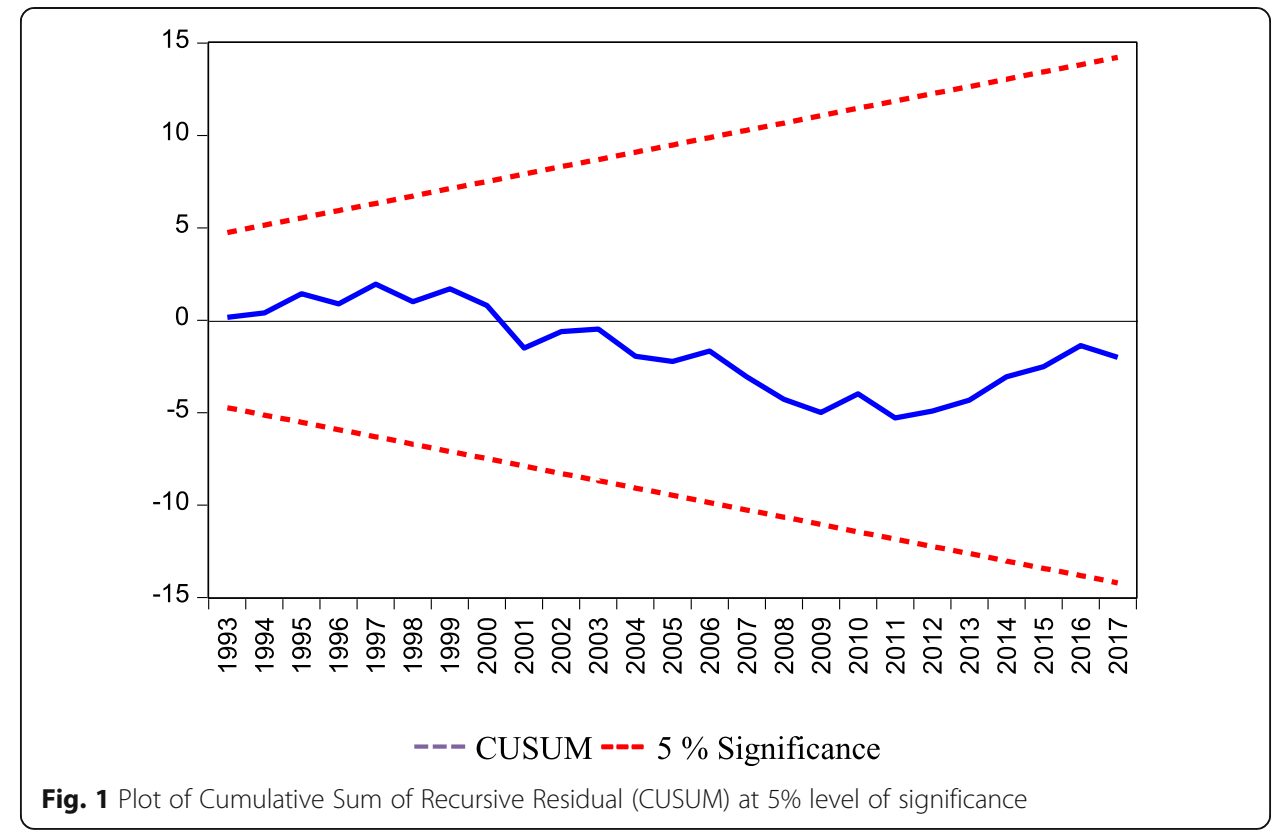

constancy of the coefficient of the long-run model in the sample period. CUSUM and CUSUM of square test results indicate that the coefficient of the long run ARDL is stable. The results of the above figures show that the blue line is in the range of critical bonds, so it indicates that the ARDL model is stable.

\section{Conclusions and recommendations}

This research paper investigated the effect of different macroeconomic factors on the exchange rate of the Chinese Yuan. Time series data were used from 1980 to 2017 for statistical analysis. Results of Co-integration indicated that long run association exists between gross domestic product growth, inflation rate, interest rate, trade openness

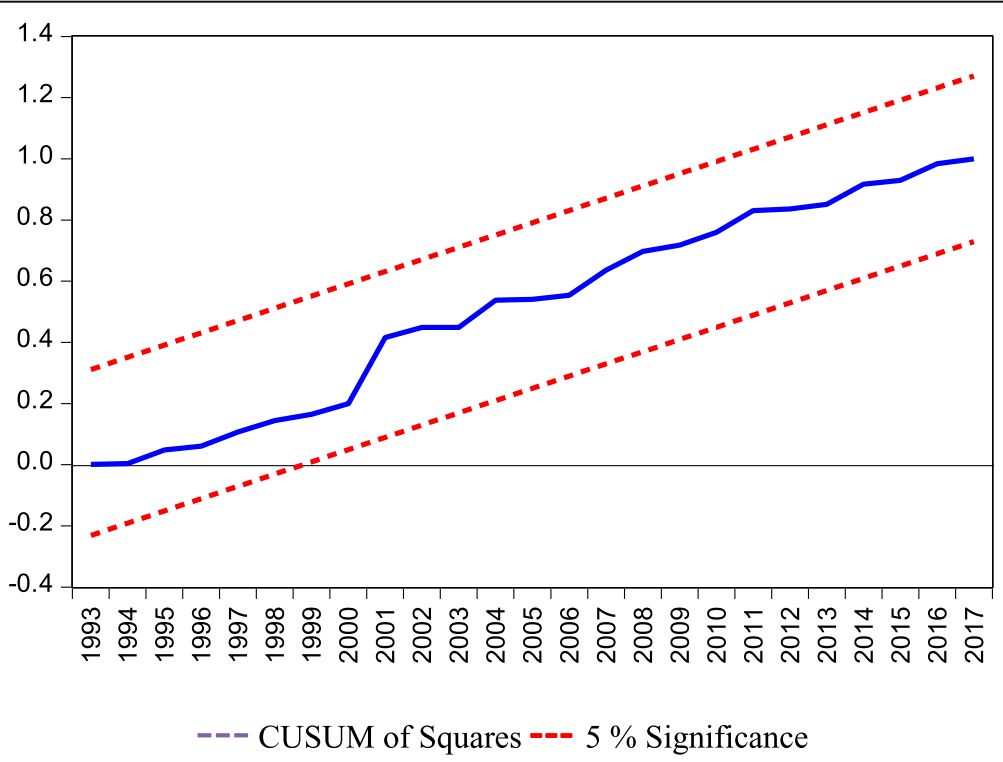

Fig. 2 Plot of Cumulative Sum of The Square of Recursive Residuals (CUSUMQ) at 5\% level of significance 
and exchange rate USD/CNY. Long run ARDL approach results indicate that inflation and interest rate have a negative effect on exchange rate while gross domestic product growth and trade openness have a positive effect on exchange rate USD/CNY in China. Trade openness plays a very important role to appreciate the value of the Chinese Yuan because with trade openness China exports its products to other developed and developing countries that is a source of foreign reserve for China economy. Based on the results of this study, the policymakers of the Chinese government should motivate its government to assign such monetary and fiscal policies that cause less volatile and productive exchange rate for China to manage sustainable economic growth for a long time with its trading partners.

\section{Abbreviations}

ADF: Augmented dickey fuller; ARDL: Autoregressive distributed lag; ECM: Error correction model; EXCR: Exchange rate; GDPG: Gross domestic product growth; INFR: inflation rate; INTR: Interest rate; PP: Phillips and perron; TRDO: Trade openness

\section{Acknowledgements}

We are very thankful to all friends for their help and suggestion their valuable comments regarding this research paper. We are very thankful to Editorial Board of the Financial Innovation for their editorial efforts. We are also thankful to three anonymous reviewers for their careful reading of our manuscript and their valuable suggestions. Currently this research paper did not receive any financial aid from any source.

\section{Availability of data and materials}

The data used in this research paper were obtained from Federal researve bank of ST. Louis website: https:// fred.stlouisfed.org/

\section{Authors' contributions}

JZT is the corresponding author and provides the ideas of this paper. MKK is the first author to complete the construction and writing of this paper. MIK is the third author and collected the data. All authors read and approved the final manuscript.

\section{Competing interests}

The authors delare that they have no competing interests.

\section{Publisher's Note}

Springer Nature remains neutral with regard to jurisdictional claims in published maps and institutional affiliations.

Received: 27 August 2018 Accepted: 27 December 2018

Published online: 31 January 2019

\section{References}

Abbas Q, lqbal J, Ayaz L (2012) Relationship between GDP, inflation and real interest rate with exchange rate fluctuation of African countries. Int J Acad Res Account Finance. Manage Sci 2(3):132-141

Algieri B (2011) The Dutch disease: evidences from Russia. Econ Chang Restruct 44(3):243-277

Arghyrou MG, Pourpourides P (2016) Inflation announcements and asymmetric exchange rate responses. J Int Financ Mark Inst Money 40:80-84

Azid T, Jamil M, Kousar A, Kemal MA (2005) Impact of exchange rate volatility on growth and economic performance: a case study of Pakistan, 1973-2003 [with comments]. Pak Dev Rev 44(4):749-775

Bahmani-Oskooee M, Tanku A (2006) Black market exchange rate, currency substitution and the demand for money in LDCs. Econ Syst 30(3):249-263

Bailliu J, Lafrance R, Perrault JF (2003) Does exchange rate policy matter for growth? Int Finance 6(3):381-414

Chowdhury M, Hossain MT (2014) Determinants of exchange rate in Bangladesh: a case study. J Econ Sustain Dev 5:1. Available at SSRN: https://ssrn.com/abstract=2668804

Clostermann J, Schnatz B (2000) The determinants of the euro-dollar exchange rate-Synthetic fundamentals and a nonexisting currency. Deutsche bundesbank working paper No. 02/00. https://doi.org/10.2139/ssrn.229472 Available at SSRN: https://ssrn.com/abstract=229472

Dickey DA, Fuller WA (1979) Distribution of the estimators for autoregressive time series with a unit root. J Am Stat Assoc 74(366a):427-431

Drine I, Rault C (2006) Learning about the long-run determinants of real exchange rates for developing countries: A panel data investigation. In: Panel Data Econometrics Theoretical Contributions and Empirical Applications (Contributions to Economic Analysis, Volume 274). Emerald group publishing limited, pp 307-325

Ebiringa OT, Anyaogu NB (2014) Exchange rate, inflation and interest rates relationships: Autogressive distributive lag analysis. J Econ Dev Stud 2:263-279

Elbadawi IA, Soto R (1997) Real exchange rates and macroeconomic adjustments in sub-Saharan Africa and other developing countries. J Afr Econ 6(3):74-120 
Engel C, Rogers JH (2001) Deviations from purchasing power parity: causes and welfare costs. J Int Econ 55(1):29-57 Engle RF, Granger CW (1987) Co-integration and error correction: representation, estimation, and testing. Econometrica:251-276 Fisher I (1930) The theory of interest, vol 43. The Macmillan Company, New York

Gente K, León-Ledesma MA (2006) Does the world real interest rate affect the real exchange rate? The south east Asian experience. J Int Trade Econ Dev 15(4):441-467

Gujarati DN (2003) Basic Econometrics. McGraw-Hill, New York. https://doi.org/10.1186/s40854-018-0117-x

Harberger A (2003) Economic growth and the real exchange rate. Revisiting the balassa-samuelson effect, conferencia presentada en the higher school of economics, Moscú

Hau H (2002) Real exchange rate volatility and economic openness: theory and evidence. J Money, Credit, Bank 34(3):611-630

Haug AA (2002) Temporal aggregation and the power of cointegration tests: a Monte Carlo study. Oxf Bull Econ Stat 64(4): 399-412

Iqbal N, Khattak SR, Khattak MA, Ullah I (2012) Testing the arbitrage pricing theory on Karachi stock exchange. Interdiscip J Contemp Res Bus 4(8):839-853

Johansen S, Juselius K (1990) Maximum likelihood estimation and inference on cointegration—with applications to the demand for money. Oxf Bull Econ Stat 52(2):169-210

Joyce J, Kamas L (2003) Real and nominal determinants of real exchange rates in Latin America: short-run dynamics and long-run equilibrium. J Dev Stud 39(6):155-182

Khan MA, Qayyum A (2011) Exchange rate determination in Pakistan: role of monetary fundamentals. J Econ Coop Dev 32(2):67

Khan SA (2010) Empirical study on impact of interest rate on exchange rate. https://doi.org/10.2139/ssrn.1625492. Available at SSRN: https://ssrn.com/abstract=1625492

Kulkarni KG, Ishizaki M (2002) Purchasing power parity theory revisited: recent evidence from US Dollar and Japanese yen. Glob Bus Rev 3(1):53-61

Kumar S (2010) Determinants of real exchange rate in India: an ARDL approach. Reserv Bank India Occas Pap 31(1):33-64 Lane PR, Milesi-Ferretti GM (2012) External adjustment and the global crisis. J Int Econ 88(2):252-265

Lartey EK, Mandelman FS, Acosta PA (2008) Remittances, exchange rate regimes and the Dutch disease: a panel data analysis. Rev Int Econ 20(2):377-395

Liew VKS, Baharumshah AZ, Puah CH (2009) Monetary model of exchange rate for Thailand: long-run relationship and monetary restrictions. Glob Econ Rev 38(4):385-395

MacDonald R, Ricci LA (2005) The real exchange rate and the Balassa-Samuelson effect: the role of the distribution sector. Pac Econ Rev 10(1):29-48

Mallick H (2010) Factors determining the exchange rate movement under a partial capital mobility regime. Int Econ J 24(2):249-266

McPherson MF, Rakovski T (2000) Exchange rates and economic growth in Kenya: an econometric analysis

Mirchandani A (2013) Analysis of macroeconomic determinants of exchange rate volatility in India. Int J Econ Financ Issues 3(1):172-179

Moffett MH, Stonehill Al, Eiteman DK (2016) Fundamentals of multinational finance, 5th edn. Addison-Wesley, Pearson (The Pearson Series in Finance)

Moffett MH, Stonehill Al, Eiteman DK (2017) Fundamentals of multinational finance, 6th edn. Addison-Wesley, Pearson (The Pearson Series in Finance)

Morrison WM, Labonte M (2013) China's currency policy: an analysis of the economic issues. Curr Pol Econ North West Asia 22(4):507

Namjour RP, Gholizadeh MH, Haghighi MBN (2014) Survey the relationship between exchange rates and inflation rate in the first two years of fifth development plan. Universal J Manage Soc Sci 4(3):31-40

Necșulescu Cl, Șerbănescu LL (2013) Impact of the inflation on the exchange rate and on the average salary. Cross Cult Manage J 29:222-227

Neumeyer PA, Perri F (2005) Business cycles in emerging economies: the role of interest rates. J Monet Econ 52(2):345-380

Nucu AE (2011) The relationship between exchange rate and key macroeconomic indicators. Case study: Romania. The Romanian. Econ J 41:127-145

Ozturk I, Acaravci A (2011) Electricity consumption and real GDP causality nexus: evidence from ARDL bounds testing approach for 11 MENA countries. Appl Energy 88(8):2885-2892

Pesaran MH, Shin Y (1999) An autoregressive distributed-lag modelling approach to cointegration analysis. Econ Soc Monogr 31:371-413

Pesaran MH, Shin Y, Smith RJ (2001) Bounds testing approaches to the analysis of level relationships. J Appl Econ 16:289-326 https://doi.org/10.1002/jae.616

Phillips PC, Perron P (1988) Testing for a unit root in time series regression. Biometrika 75(2):335-346

Piana V (2001) Exchange rate. Retrieved April 20:2010

Raza SA, Afshan S (2017) Determinants of exchange rate in Pakistan: revisited with structural break testing. Glob Bus Rev 18(4):825-848

Siddiqui R, Afridi U, Mahmood Z, Bhatti RH (1996) Exchange rate determination in Pakistan: a simultaneous equation model [with comments]. The. Pak Dev Rev:683-692

Smith CE (1999) Exchange rate variation, commodity price variation and the implications for international trade. J Int Money Financ 18(3):471-491

Tafa J (2015) Relationship between exchange rates and interest rates: case of Albania. Mediterr J Soc Sci 6(4):163

Wong HT (2013) Real exchange rate misalignment and economic growth in Malaysia. J Econ Stud 40(3):298-313

Xiaopu Z (2002) Equilibrium and misalignment: an assessment of the RMB exchange rate from 1978 to 1999. Centre for research on economic development and policy reforms. Working Paper No. 127, Stanford, pp 1-27

Zeileis A, Shah A, lla P (2007) Exchange rate regime analysis using structural change Methods. Research Report Series / Department of Statistics and Mathematics. Department of Statistics and Mathematics. WU Vienna University of Economics and Business, Vienna, p 56

Zeileis A, Shah A, Patnaik I (2005) What is the new Chinese currency regime? Research Report Series / Department of Statistics and Mathematics. Department of Statistics and Mathematics. WU Vienna university of economics and business, Vienna, p 23 